\title{
Medicinal properties of Zingiber officinale Roscoe - A Review
}

\author{
Subash kumar Gupta ${ }^{1}$, Anand Sharma ${ }^{2}$ \\ ${ }^{1}$ (Department of Botany, Pakim Palatine College, Sikkim University, Sikkim, India). \\ ${ }_{2}^{2}$ (Department of Botany, North Bengal University, West Bengal, India).
}

\begin{abstract}
Ginger (Zingiber officinale) belong to Zingiberacae family is one of the famous spices all over the world. It is a perennial creeping plant with long leaves, yellow green flowers and thick tuberous rhizome. This is a type of storage root having pungent taste. Ginger has a long history of medicinal use for more than 2000 years as one of the most versatile medicinal plants having a wide spectrum of biological activity. From ancient times ginger has been exploited both as Ayurvedic and Chinese medicine for curing heart problems, menstruation disorder, food poisoning, osteoarthritis, epilepsy, nausea, inflammation, cough and cold, motion sickness, menstrual cramps, cancer and many more. Besides these it also exhibits antimicrobial and antioxidant properties. The medicinal properties of ginger are due to the presence of gingerol and paradol, shogaols, etc. Medicinal value of ginger and its knowledge provide the good platform for researchers for future research to protect human beings from several types of diseases.

Key words: Antioxidant, ayurvedic, gingerol, Zingiber officinale.
\end{abstract}

\section{Introduction}

Medicinal plants have a long history of use for the beneficial of mankind. According to the report of the World Health Organization (W.H.O.) about $80 \%$ of the world's populations rely mainly on traditional therapies which involve the use of plant extracts or their active substances [1]. Medicinal plants play an important role in traditional health care systems for curing many diseases. The medicinal value of these plants lies in some chemical substances that produce a definite physiological action on human body. Ginger is an important plant with several medicinal, ethno medicinal and nutritional values [2]. Ginger is the underground rhizome of the ginger plant with a firm, striated texture. Zingiber officinale Roscoe, commonly known as ginger belongs to family Zingiberaceae. The cultivation of ginger is known to originate in China which then spread to India, South East Asia, West Africa and the Caribbean [3, 4]. India is the biggest producer of ginger in the world. In India, it is cultivated in almost all the states. Some reports suggests that the climatic conditions of Orissa, West Bengal, North Eastern states and Kerala are more suitable for the growth of ginger in India [5]. The medicinal use of ginger is well known in India and its neighboring countries for more than 2000 years as one of the most versatile medicinal plants. Ginger has been using both as Ayurvedic and Chinese medicine for curing heart problems, treat stomach upset, diarrhea, and nausea [6]. It is also used as a disguise the taste of medicines; promotes the release of bile from the gall bladder [7, 8], decrease joint pain from arthritis, useful for the treatment of heart diseases and lungs diseases [9]; relief cough and cold, throat infection [10]. Besides these it is used as curry powder, hot drinks like ginger beer, ginger wine, ginger tea. Ginger has been identified as an herbal medicinal product with pharmacological effect. Ginger suppresses prostaglandin synthesis through inhibition of cyclooxygenase- 1 and cyclooxygenase- 2 . Many research has been showed that the ginger extract also have antimicrobial activity and anti-oxidant properties.

\section{Systematic position and morphology}

The family zingiberaceae is represented by about 46 genera, distributed through the tropics and subtropics. The type genus of this family is Zingiber. The plant is an aromatic herb and its taxonomic position is as follows:

Table 1. Scientific classification

\begin{tabular}{ll}
\hline Kingdom & Plantae \\
Division & Magnoliophyta \\
Class & Liliopsida \\
Order & Zingiberales \\
Family & Zingiberaceae \\
Genus & Zingiber \\
Species & Z. officinale \\
\hline
\end{tabular}

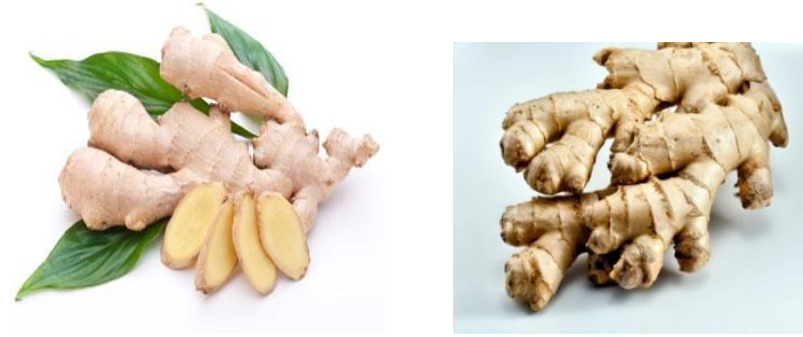

Fig. 1 Rhizome of Zinger officinale 
The ginger plant has a perennial, tuberous root or rhizome; the stems are erect, oblique, round, annual, and invested by the smooth sheaths of the leaves, 2 or 3 feet in height, yellow green flowers and thick tuberous rhizome. Laterally compressed rhizomes are 7-15 cm long and 1-1.5 cm broad. About 1-3 cm long branches arise and terminate in depress scars or in undeveloped buds. The flesh of the ginger rhizome can be yellow, white or red in color, depending upon the variety. It is covered with a brownish skin that may either be thick or thin, depending upon whether the plant was harvested when it was mature or young.

\section{Chemical composition}

In the fresh ginger rhizome, the gingerols were identified as the major active components [11]. The sensory perception of ginger arises from two distinct groups of chemical namely volatile oils and non-volatile pungent compounds. The volatile oil components in ginger consists mainly of sesquiterpene hydrocarbons, predominantly zingeberene (35\%), curcumene (18\%) and farnesene (10\%) [12]. Many of these volatile oil constituents contribute to the distinct aroma and taste of ginger. Non-volatile pungent compounds include gingerols, shogaols, paradols and zingerone that produce a 'hot' sensation in the mouth (Fig 2). The gingerols, a series of chemical homologs differentiated by the length of their unbranched alkyl chains, were identified as the major active components in the fresh rhizome. In addition, the shogaols, another homologous series and the dehydrated form of the gingerols are the predominant pungent constituents in dried ginger. Paradol is similar to gingerol and is formed on hydrogenation of shogoal. Other constituent in addition is oleoresins. Ginger contains fats, waxes, carbohydrates, vitamins and minerals. Ginger rhizomes also contain a potent proteolytic enzyme called zingibain.<smiles>CCCC(O)CC(=O)CCc1ccc(O)c(O)c1</smiles>

Singerol<smiles>CCCCCC(=O)CCc1ccc(O)c(O)c1</smiles>

Paradol<smiles>CCCCCCC(=O)CCc1ccc(O)c([N+](=O)[O-])c1</smiles>

Shogoal<smiles>CCCC(=O)CC(O)CCc1ccc([N+](=O)[O-])c(OC)c1</smiles>

Methyl [6] - isogingerol

Fig 2. Non-volatile pungent components of ginger. Source: [13]

\section{Nutritional profile}

The nutritional compositions of dry ginger are depicted in (Table 2). Protein fat, ash, iron, calcium and phosphorous contents was $5.98 \mathrm{~g}, 4.37 \mathrm{~g}, 4.53 \mathrm{~g}, 9.41 \mathrm{mg}, 104.02 \mathrm{mg}$ and $204.75 \mathrm{mg}$ per $100 \mathrm{~g}$ respectively on dry weight basis. Similarly, the trace minerals namely zinc, copper, manganese and total chromium are $1.08 \mathrm{mg}$, $0.641 \mathrm{mg}$ and $10.74 \mathrm{mg}$ and total chromium are $83.37 \mu \mathrm{g}$ per $100 \mathrm{~g}$ respectively. Vitamin $\mathrm{C}$ and total carotenoids content found to be 10.97 and $92.96 \mathrm{mg}$ per $100 \mathrm{~g}$ respectively. Ginger extract also contains polyphenol compounds ([6]-gingerol and its derivatives) which possess high antioxidant activity. Although the digestion stimulating effect of this spice became known a long time ago, the stimulating effect on peptic juices, such as gastric juice, bile, pancreatic and intestinal juices, was discovered later. Bile acids play a major role in the uptake of fats and each upset in the metabolism of fats would hinder food digestion as a whole, because the fatty particles cover the other food elements and make them inaccessible for the action of the digestive enzymes. Lipase is the other key factor which plays a vital role in fat digestion. When ginger was included in animal diets; it was found that there was a considerable increase in the pancreatic and intestine lipase [14]. 
Table 2. Top ten Zinger producing countries of the world

\begin{tabular}{lll}
\hline S1. No & Country & Production (Tonnes) \\
\hline 1 & India & 380,100 \\
2 & China & 331,393 \\
3 & Indonesia & 192,500 \\
4 & Nepal & 174,268 \\
5 & Thailand & 170,125 \\
6 & Nigeria & 152,106 \\
7 & Bangladesh & 72,608 \\
8 & Japan & 52,000 \\
9 & Philippines & 27,415 \\
10 & Cameroon & 12,000 \\
& & $\mathbf{1 , 6 1 5 , 9 7 4}$ \\
\hline
\end{tabular}

Source: Food and agricultural Organization of United Nations: Economic and social Department: The statistical Division (2008) [15]

Table 3. Nutritional composition of ginger (per $100 \mathrm{~g} \mathrm{dw}$ )

\begin{tabular}{llll}
\hline Constituents & Value & Constituents & Value \\
\hline Moisture & $15.02 \pm 0.04$ & Ash $(\mathrm{g})$ & $3.85 \pm 0.61(4.53)$ \\
Protein $(\mathrm{g})$ & $5.087 \pm 0.09(5.98)$ & Calcium $(\mathrm{mg})$ & $88.4 \pm 0.97(104.02)$ \\
Fat $(\mathrm{g})$ & $3.72 \pm 0.03(4.37)$ & Phosphorous $(\mathrm{mg})$ & $174 \pm 1.2(204.75)$ \\
Insoluble fibre (\%) & $23.5 \pm 0.06(27.65)$ & Iron $(\mathrm{mg})$ & $8.0 \pm 0.2(9.41)$ \\
Soluble fibre $(\%)$ & $25.5 \pm 0.04(30.0)$ & Zinc $(\mathrm{mg})$ & $0.92 \pm 0(1.08)$ \\
Carbohydrate $(\mathrm{g})$ & $38.35 \pm 0.1$ & Copper $(\mathrm{mg})$ & $0.545 \pm 0.002(0.641)$ \\
Vitamin C (mg) & $9.33 \pm 0.08(10.97)$ & Manganese $(\mathrm{mg})$ & $9.13 \pm 001(10.74)$ \\
Total carotenoids $(\mathrm{mg})$ & $79 \pm 0.2(92.96)$ & Chromium $(\mu \mathrm{g})$ & $70 \pm 0(83.37)$
\end{tabular}

All values in this table represents the mean $\pm \mathrm{SD}(\mathrm{n}=4)$

Source: [17]

Table 4. Vitamin contents of ginger

\begin{tabular}{lll}
\hline Sl.No & Vitamins & Raw ginger root (per 100 g) \\
\hline 1 & Thiamine (B1) & $0.025 \mathrm{mg}$ \\
2 & Riboflavin (B2) & $0.034 \mathrm{mg}$ \\
3 & Niacin (B3) & $0.75 \mathrm{mg}$ \\
4 & Panthenic acid (B5) & $0.203 \mathrm{mg}$ \\
5 & Vitamin B6 & $0.16 \mathrm{mg}$ \\
6 & Folate (B9) & $11 \mu \mathrm{g}$ \\
7 & Vitamin C & $5 \mathrm{mg}$ \\
8 & Vitamin E & $0.26 \mathrm{mg}$ \\
\hline Source : [16]
\end{tabular}

\section{Medicinal Properties}

Medicinal plants provide rich source of novel drugs, modern medicines, food supplements, folk medicines, pharmaceutical intermediates, bioactive principles and lead compounds in synthetic drugs. Ginger has been used as traditional medicine since ancient time. Ginger is considered as a medicinal plant as it has several curative properties in treating different diseases. Following are the some of medicinal properties of Zingiber Officinale.

\section{1, Traditional ayruvedic medicine}

Ginger plays an important role in traditional Indian Ayurvedic medicine. It is also used as an ingredient in traditional Indian drinks. Fresh ginger is one of the main spices used for making dishes, both vegetarian and non vegetarian based foods. Indian traditional medicinal remedies especially for cough and asthma consists of juice of fresh ginger with a little juice of fresh garlic mixed with honey. It is also suggests 1-2 tea spoons of ginger juice with honey is a potent cough suppressant. Besides these ginger is very often used to cure many illness such as indigestion, tastelessness, loss of appetite, flatulence, intestinal, nausea, vomiting, allergic reactions, acute and chronic cough, common cold, fever, allergic rhinitis, sinusitis, acute chronic bronchitis, respiratory troubles, pain, headache, backache or any kind of muscular catch, painful tooth and swelled gum etc.[2]. 


\section{2, Gastrointestinal relief}

Modern scientific research has revealed that ginger possesses numerous therapeutic properties including antioxidant effects, an ability to inhibit the formation of inflammatory compounds, and direct antiinflammatory effects. Ginger is very effective in preventing the symptoms of motion sickness, especially seasickness. Ginger reduces all symptoms associated with motion sickness including dizziness, nausea, vomiting, and cold sweating [18]. Some active components of ginger are reported to stimulate digestion, absorption, relieve constipation and flatulence by increasing muscular activity in the digestive tract $[19,20]$.

\section{3, Anti-Inflammatory Effects}

Ginger contains potent anti-inflammatory compounds called gingerols. These substances are believed to explain why so many people with osteoarthritis or rheumatoid arthritis experience reductions in their pain levels and improvements in their mobility when they consume ginger regularly. One of the mechanisms by which ginger exerts its ameliorative effects could be related to inhibition of prostaglandin and leukotriene biosynthesis [21].

\section{4, Effect on cardiovascular system}

Ginger stimulates heart muscles, stimulates blood circulation throughout the body. The increased blood circulation is believed to stimulate cellular metabolic activity which helps to relief the cramps and tension. It also helps to reduce blood pressure and cardiac workload [22].

\section{5, Hypoglycemic and hyperglycemic activity}

Hypoglycemic potential of ginger was reported in streptozotocin induced diabetic rats. Treatment with aqueous extract $(500 \mathrm{mg} / \mathrm{kg}$ body weight) for a period of 7 weeks significantly decreased the serum glucose, cholesterol and triacylglycerol levels in the treated diabetic rats compared with the control diabetic rats [23]. Fresh juice of ginger was reported to possess hyperglycemic activity. The fresh juice of ginger $(4 \mathrm{ml} / \mathrm{kg}$ body weight) produced a significant time dependent decrease in blood glucose level in streptozotocin induced diabetic rats [24]. The juice of ginger was also reported to control type I diabetes [25].

\section{6, Cancer preventive effects}

Ginger has been found to be anti-carcinogenic via multiple pathways [26, 7] and reported to have colon cancer chemopreventive activity. Gingerol also inhibited the growth of human colorectal cancer cells [28]. In his first experiment, mice were fed with ginger before and after tumor cells were injected. In the second set of experiments, ginger was fed only after their tumors had grown to a certain size. The efficacy of ginger was found to be significant in both cases.

\section{7, Breast cancer}

The effects of chronic treatment with hot water extract of ginger rhizome on spontaneous mammary tumorigenesis have been examined in mice. In mice given free access to extract of ginger $(0.125 \%)$ in drinking water, the development of mammary tumors was significantly inhibited [29].

\section{8, Ginger induces Cell Death in Ovarian Cancer Cells}

Gingerols, the active phytonutrients in ginger, kill ovarian cancer cells by inducing apoptosis (programmed cell death) and autophagocytosis (self-digestion). A pro-inflammatory state is thought to be an important contributing factor in the development of ovarian cancer. In the presence of ginger, a number of key indicators of inflammation (vascular endothelial growth factor, interleukin-8 and prostaglandin E2) were also decreased in the ovarian cancer cells [30].

\section{9, Larvicidal activity}

Larvicidal activity of isolated compounds from the rhizome of ginger was reported against Adese aegypti and Culex quinquefasciatus. The study reported the larvicidal activity of (4) gingerol, (6)dehydrogingerdione and (6)-dihydrogingerdione against fourth instar larvae of A. aegypti (LC50 4.25, 9.80, $18.20 \mathrm{ppm})$ and $C$. quinquefasciatus $\left(\mathrm{LC}_{50} 5.52,7.66,27.24 \mathrm{ppm}\right)$, respectively. Similarly, larvicidal activity of ginger was reported against Angiostrongylus Cantonensis, a roundworm. A. cantonens is a parasitic nematode which causes angiostrongyliasis, the most common cause of eosinophilic meningitis in Southeast Asia and the Pacific Basin. In the study, [6]-gingerol were isolate from the roots of ginger and screened for larvicidal activity against the larvae of $A$. cantonensis [2]. 


\section{Immune Boosting Action}

Ginger not only helps to keep warm in colder days, it also promotes healthy sweating, which is often helpful during colds and flus. A good sweat may do a lot more than simply assist detoxification. It provides protection against invading microorganisms, including bacteria such as E. coli and Staphylococcus aureus (a common cause of skin infections) and fungi, including Candida albicans. Ginger essential oil showed the improvement in humoral immune response in immune suppressed mice [31].

\section{1, Antioxidant activity}

Ginger roots extracts contain polyphenol compounds (6-gingerol and its derivatives), which have a high antioxidant Activity. Antioxidant compounds are widely used compounds to counter the free radicals mediate oxidative stress in the cell. Antioxidant activity is due to the presence of flavones, isoflavones, flavonoids, anthocyanin, coumarin, lignans, catechins and isocatechins. The total phenolic content in the alcoholic extract of the dried rhizome of ginger was $870.1 \mathrm{mg} / \mathrm{g}$ extract. Extract exhibited $90.1 \%$ of DPPH radical scavenging activity with the $\mathrm{IC}_{50}$ concentration of $0.64 \mu \mathrm{g} / \mathrm{ml}$ [32]. Antioxidant property of ginger is an extremely significant activity which can be used as a preventive agent against a number of diseases.

\section{2, Antimicrobial activity of ginger}

Ginger has been traditionally exploited for having broad range of antimicrobial activity against both gram positive and gram negative bacteria and fungi. In vitro studies have shown that active constituents of ginger inhibit multiplication of colon bacteria, these bacteria ferment undigested carbohydrates causing flatulence, this can be counteracted with ginger [33]. It inhibits the growth of Escherichia coli, Proteus sp, Staphylococci, Streptococci and Salmonella [34]. Ginger has strong antibacterial activity and to some extent antifungal properties [35]. Ginger inhibits Aspergillus sp, a fungus known for the production of aflatoxin, a carcinogen [36]. Fresh ginger juice showed inhibitory action against Aspergillus niger, Sacharomyces cerevisiae, Mycoderma sp. and Lactobacillus acidophilus. Thus, ginger which is a normal ingredient of our routine food preparations can provide protection against our natural enemies like bacterial and fungal pathogens.

\section{Conclusion}

Medicinal plants are a source of great economic value throughout the world. Zingiber officinale, is an important plant with several medicinal, ethno medicinal and nutritional values used in traditional medicine. Ginger is consumed worldwide as a spice and flavoring agent and is attributed to have many medicinal properties. Ginger has a number of chemical responsible to provide different medicinal properties such as cardio-protective, anti-inflammatory, anti-microbial, antioxidant, anticancer properties, etc. We hope this review will help the scientific researchers to facilitate all necessary information about the ginger as a one of the important medicinal plant and development work should be undertaken for the production of pharmaceutical products for their better economic and therapeutic utilization for the benefit of mankind.

\section{Acknowledgement}

The authors wish to thank the Chairman and Principal of Pakim Palatine College (Affiliated to Sikkim University), East Sikkim, India for their kind inspiration to publish this review article.

\section{References:}

[1]. A, Sofowora, Introduction to medical plants and traditional medicine. Spectrum books limited, 2, (1999), 8-76.

[2]. G. Kumar, L. Kathie and K. V. B. Rao, A review on pharmacological and phytochemical properties of Zingiber officinale Roscoe (Zingiberaceae), Journal of Pharmacy Research, 4(9), (2011), 2963-2966.

[3]. E. A. Weiss, Essential Oil Crops, $C A B$ International, Oxon, UK and New York (1997), 76

[4]. H, McGee, On food and cooking, in H.McGee (Ed.), The science and lore of the kitchen. 2nd Edition. (New York, 2004) $425-426$.

[5]. P. Utpala, A.K. Johny, V.A. Parthasarathy, K. Jayarajan and M.S. Madan, Diversity of ginger cultivation in India - a GIS study, Journal of Spice and Aromatic Crop, 15 (2), (2006), 93-99.

[6]. Y. Shukla and M. Singh, Cancer preventive properties of zinger: a brief review, Food and Chemical Toxicology, 45(5), (2007), 683-690.

[7]. M. Kato, M. L. Rocha, A. B, Carvallo, M.E. Chaves, M.C. Rana, and F. C. Olverra, Occupational exposure to neurotoxicants. Preliminary survey in five industries of caricari petrochemical complex. Brazil Environ.Res. 61, (1993), 133-139.

[8]. M. O'Hara, D, Keifer, K, Farrel and K, Kemper, A review of 12 commonly used medicinal herbs. Archives of Family Medicin, 7(6), (1998), 523-536.

[9]. D. L. J. Opdyke, Food Cosmet. Toxicology. 12 (Suppl.), (1974), 901.

[10]. D.V.C. Awang, Ginger. Canadian Pharmaceutical Journal, 125 (7), (1992), 309-311.

[11]. T. Hoffman, Antimicrobial activity of some medicinal plants from India. Hawaii Medical Journal, 66, (2007), $326-327$.

[12]. V. Govindarajan, Ginger-chemistry technology and quality evaluation: Part-I CRC. Critical Reviews in Food Science and Nutrition, 17, (1982), 1-96.

[13]. A.K. Ghosh, S. Banerjee, H.I. Mullick and J. Banerjee, Zingiber officinale: a natural gold, International Journal of Pharma and Bio Sciences, 2, (2011), 283-294. 
[14]. K, Platel and K, Srinivasan, Influence of dietary spices and their active principles on pancreatic digestive enzymes in albino rats. Nahrung, 1, (2000), 42-46.

[15]. Food and agricultural Organization of United Nations: Economic and social Department: The statistical Division (2008), P. 2

[16]. www.wikipedia.org. Ginger, Dated 15.09.2014.

[17]. S. Adel and P, Prakash, Chemical composition and antioxidant properties of ginger root (Zingiber officinale), Journal of Medicinal Plants Research, 4(24), (2010), 2674-2679.

[18]. J. Yamahara and Q. Huang, Gastrointestinal motility enhancing effect of ginger and its active constituents. Chemical and Pharmaceutical bulletin, 38(2), (1990), 430- 431.

[19]. J. Stewart, M.J. Wood, C.D. Wood and M.E. Mims, Effects of ginger on motion sickness susceptibility and gastric function. Pharmacology, 42(2), (1991), 111-120.

[20]. D.B. Mowrey and D.E. Clayson, Motion sickness, ginger and psychophysics. Lancet, i (1982), 655-657

[21]. F. Kiuchi, S. Iwakami, M. Shibuya, F. Hanaoka and U. Sankawa, Inhibition of prostaglandin and leukotriene biosynthesis by gingerols and diaryl heptanoids. Chemical and Pharmaceutical Bulletin, 40(2), (1992), 387-391.

[22]. A.K. Ghosh, S. Banerjee, H.I. Mullick and J. Banerjee, Zingiber officinale: a natural gold, International Journal of Pharma and Bio Sciences, 2(1), (2011), 283-294.

[23]. Z.M. Al-Amin, M. Thomson, K.K. Al-Qattan, R. Peltonen-Shalaby, M. Ali, Antidiabetic and hypolipidaemic properties of ginger (Zingiber officinale) in streptozotocin-induced diabetic rats, British Journal of Nutrition, 96(4), (2006), 660-666.

[24]. B. Asha, K.H. Krishnamurthy and S. Devaru, Evaluation of anti hyperglycaemic activity of Zingiber officinale (Ginger) in albino rats, Journal of Chemical and Pharmaceutical Research, 3(1), (2011), 452- 456.

[25]. S.P. Akhani, S.L. Vishwakarma, R.K. Goyal, Anti-diabetic activity of Zingiber officinale in streptozotocin-induced type I diabetic rats, Journal of Pharmacy and Pharmacology, 56(1), (2004), 101-105.

[26]. K. Koshimizu, H. Ohigashi, H. Tokuda, A. Kondo and K. Yamaguchi, Screening of edible plants against possible anti-tumor promoting activity. Cancer Letters 39, (1988), 247-257.

[27]. S.K. Katiyar, R. Agarwal, H. Mukhtar, Inhibition of tumor promotion in SENCAR mouse skin by ethanol extract of Zingiber officinale rhizome. Cancer Research, 56(5), (1996), 1023-1030.

[28]. A. Bode, Ginger is an effective inhibitor of HCT 116 human colorectal carcinoma in vivo. Paper presented at the Frontiers in Cancer Prevention Research Conference, Phoenix, AZ, October 26-30, (2003).

[29]. H. Nagasawa, K. Watanabe, H. Inatomi, Effects of bitter melon (Momordica charantia 1.) or ginger rhizome (Zingiber offifinale rosc) on spontaneous mammary tumorigenesis in SHN mice. American Journal of Chinese Medicine, 30(2-3), (2002), 195-205.

[30]. J.M. Rhode, J. Huang, S. Fogoros, L. Tan, S. Zick, J.R. Liu, Ginger induces apoptosis and autophagocytosis in ovarian cancer cells. Abstract no. 4510, presented April 4, 2006 at the 97th AACR Annual Meeting, April 1-5, 2006, Washington, DC.

[31]. F.R. Carrasco, G. Schmidt, A.L. Romero, J.L. Sartoretto, S.M. Caparroz-Assef, C.A. Bersani-Amado and R.K. Cuman, Immunomodulatory activity of Zingiber officinale Roscoe,Salvia officinalis L. and Syzygium aromaticum L. essential oils: evidence for humor- and cell-mediated responses. Journal of Pharmacy and Pharmacology, 61(7), (2009), 961-967.

[32]. I. Stoilova, A. Krastanov, A. Stoyanova, P. Denev and S. Gargova, Antioxidant activity of a ginger extract (Zingiber officinale), Food Chemistry, 102(3),(2007), 764-770.

[33]. S. Gupta and S. Ravishankar, A comparison of the antimicrobial activity of garlic, ginger, carrot, and turmeric pastes against Escherichia coli O157:H7 in laboratory buffer and ground beef. Foodborne Pathogens and Disease, 2 (4), (2005), 330-40.

[34]. B. White, Antimicrobial activity of ginger against different microorganisms: Physician, 75, (2007), 1689-1691.

[35]. P.V. Nielsen and R. Rios, Inhibition of fungal growth on bread by volatile compounds from spices and herbs and mustard essential oil. International Journal of Food Microbiology, 60(2-3), (2000), 219-229.

[36]. S.P. Nanir and B.B. Kadu, Effect of medicinal plant extracts on some fungi. Acta Botanica Indica, 15(2), (1987), 170-175. 